\title{
Characterization of pharmaceuticals industrial effluent using GC-MS and FT-IR analyses and defining its toxicity
}

\author{
Vineeta Kumari ${ }^{1}$ - A. K. Tripathi ${ }^{1}$
}

Received: 4 June 2018 / Accepted: 2 October 2019 / Published online: 16 October 2019

(c) The Author(s) 2019

\begin{abstract}
The physicochemical analysis of collected effluent sample for different parameters shown results as $\mathrm{pH}(\mathrm{pH} 5.6 \pm 0.11)$ slightly acidic, high conductivity $\left(1563.34 \pm 176 \mu \mathrm{sm}^{-1}\right)$, total dissolved solids $\left(920.34 \pm 137 \mathrm{mg} \mathrm{L}^{-1}\right)$, high BOD $\left(7253.34 \pm 1022 \mathrm{mg} \mathrm{L}^{-1}\right)$, and COD $\left(756.67 \pm 1124 \mathrm{mg} \mathrm{L}^{-1}\right)$ in the effluent sample. The results of heavy metals concentration are viz. as [Cu (1.98-2.56), $\mathrm{Co}(0.26-0.53), \mathrm{Cd}(0.10-0.50), \mathrm{Ni}(0.04-0.07), \mathrm{Pb}(0.58-1.2), \mathrm{Mn}(0.58-1.05), \mathrm{Cr}$ (1.47-1.51), Zn (2.61-3.5), Fe (1.72-2.13), As (0.05-0.09), and Hg (0.003-0.006)]. Results revealed the higher concentration of BOD, COD, TDS, and conductivity and also the concentration of lead. Results of GC-MS also confirmed the high levels of organic pollutants in effluent. Further the effluent toxicity was evaluated by employing genotoxocity assays with the use of Allium cepa L. (onion) root tip cells. Genotoxicity measured mitotic index (MI) and chromosomal aberrations (CAs) in root tip cells obtained after treatment with effluent of $6.25,12.5$, and $25 \%$ concentration (v/v). The results of root growth test showed that inhibition of root growth occurred at effluent concentration $\geq 50 \%(\mathrm{v} / \mathrm{v})$. The lowest MI was recorded $(\mathrm{MI}=9.6 \%)$ in $25 \%$ of effluent concentration, showing a significant reduction in mitotic index compared with control which $\mathrm{MI}=64.1 \%$. Further, the chromosomal aberration was investigated in root tip cell after treating with different concentration ranges of effluent exhibiting various CA, viz. c-mitosis, chromosome loss, chromosome break, micronucleated cells, etc. The result suggests that the effluent contained toxic constituents, which imposed cytotoxic and genotoxic hazard.
\end{abstract}

Keywords Pharmaceutical industrial effluent $\cdot$ Allium cepa $\cdot$ Mitotic index $\cdot$ Chromosomal aberration $\cdot$ Micronuclei cell

\section{Introduction}

Increase in global demand for drugs has made pharmaceutical industry one of the major 26 polluters of solid wastes and effluent into the environment (Anyakora et al. 2011). According to estimates, about half of the global wastewater from pharmaceutical industries is released without any recommended preprocessing (Osaigbovo and Orhue 2006; Anetor et al. 1999).

In spite of the fact that the volume of untreated or entirely treated pharmaceutical industrial wastewater is little, it contains a high level of pollutants because of the presence of non-biodegradable organic matter such as antibiotics, other prescription drugs, non-prescription drugs, animal

Vineeta Kumari

vineeta.env@gmail.com

1 Ecology, Climate Change and Forest Influence Division, Forest Research Institute (Deemed University), Dehradun, Uttarakhand 248195, India and plant steroids, reproductive hormones, betalactamides, anti-inflammatories, analgesics, lipid regulators, anti-depressants, cytostatic agents, personal care products, detergent metabolites, flame retardants, product of oil use and combustion, and other broadly used chemicals, i.e., spent solvents, reaction residues, used filter media, etc., heavy metals (such as lead, mercury, cadmium, nickel, and chromium), and other pollutants (Babaahmadi et al. 2017; Ramola and Singh 2013; Vuppala et al. 2012; Chelliapan et al. 2011). Pharmaceutical industrial wastewater contains toxic and hazardous substances, the majority of which can be unfavorable to human well-being.

The effects of pharmaceutical chemicals on public health and environment are critical due to their acute toxicity, including genotoxicity and mutagenic potential (Nadal et al. 2004, Akintonwa et al. 2009; Bakare et al. 2009; Adeoye et al. 2015). Drugs of various types, as active metabolites or unmetabolized sometime, especially in developing countries, are not well managed on expiration and subsequently discarded in large amount as environmental discharge in the 
surrounding ecosystems. While in the environment most of the pharmaceutical are discharge toxicants present in wastewater accumulates in aquatic bodies, soil, and other biological systems, and often exceeds the critical threshold levels (Cleuvers 2003; Hernandoa et al. 2006; Larsson et al. 2007). A number of studies have identified specific chemical components in pharmaceutical effluents and demonstrated their toxic effects on living organisms (Daughton and Ternes 1999; Jones et al. 2001; Larsson et al. 2007; Idris et al. 2013). Therefore, in recent years, great concern is shown to study the impacts of discharged pharmaceutical effluents on the ecosystem and its services, and human wellness tied to them.

Becker (2010) has found out the five extensive knowledge gaps, which should be considered to get the most astounding need in terms of research to symbolize the environmental and human health impacts of pharmaceutical water pollution. These represent the key points of the pharmaceutical life cycle, from design through disposal, and are framed as questions that need to be addressed:

(1) Method to frame the prescription drugs to more advanced in form of lesser bioactivity, enhanced absorption, and reduced excretion of waste and carbon footprint.

(2) Which types of mechanisms may be used to enhance the approval and regulation of present, but new redesigned, advanced medicines using green alternative synthesis methods should be incentivized, which are least hazardous and reduce the environmental impacts.

(3) Way of procedure modification to reduce the waste discharged quantity and use of less toxic constituents in manufacturing and also reduction in the carbon footprint

(4) Does little quantity of the non-medication chronic exposure to prescription drugs within the water have an impact on the usefulness of those prescription drugs to deal with treat conditions or illnesses? What practices can be employed to lessen the amount of pharmaceutical waste among health care companies, pharmacists, insurers, and agriculture, thereby enhancing source reduction and pollutants prevention?

(5) Find out the methods of safe disposal of unused, what are the methods to make certain safe disposal of unused, objectionable, or expired prescription drugs and enhanced disposed elimination of those substances from discharged wastewater, and in the long run the potable water?

Allium cepa (onion) offers easier pathway to the assessment of chromosomal degradation and interference in mitotic cycles. This is possible because A. cepa cells have large chromosomes and in reduced numbers (Levan 1938).
Thus, this test has been broadly used to study the genotoxicity of an extraordinary assortment of environmental pollutants, such as heavy metals, pesticides, aromatic hydrocarbons, and complex mixtures of pollutants (Leme and Marin-Morales 2009).

Objective of the present study is to identify physicochemical parameters (viz. $\mathrm{pH}$, electrical conductivity (EC), total dissolved solids (TDS), BOD, COD, and heavy metals $(\mathrm{Cu}$, $\mathrm{Co}, \mathrm{Cd}, \mathrm{Ni}, \mathrm{Pb}, \mathrm{Mn}, \mathrm{Cr}, \mathrm{Zn}, \mathrm{Fe}, \mathrm{As}$, and $\mathrm{Hg}$ ) and organic pollutants in pharmaceutical effluent. The organic constituents were characterized using gas chromatography-mass spectrophotometer (GC-MS) and Fourier-transform infrared spectroscopy analyses (FT-IR). The effluent toxicity was studied by genotoxicity assays using Allium cepa $\mathrm{L}$. (onion) root tip cells. Genotoxicity studies included measuring mitotic index (MI) and chromosomal aberrations (CAs) in root tip cells following treatment with $6.25,12.5$, and $25 \%$ (v/v) of effluent.

\section{Materials and methods}

The pharmaceutical industry effluent samples were collected from Lucknow, Uttar Pradesh (India). Effluent samples were collected from industry outlet point in sterile plastic containers of $1 \mathrm{~L}$ capacity. Total three samples were collected from pharmaceutical industry at 10 days time period. Samples were brought to laboratory in icebox and stored at $4{ }^{\circ} \mathrm{C}$ and filtered with Whatman filter paper no. 42. $\mathrm{pH}$ of collected effluent was measured with a digital $\mathrm{pH}$ meter (Metrohm, USA). Electrical conductivity (EC) and total dissolved solids (TDS) were determined by a conductivity meter (Thermo Orion, model 162A, USA). Biochemical oxygen demand (BOD) and chemical oxygen demand (COD) were determined by the titration method (APHA 2005). Heavy metals $(\mathrm{Cu}, \mathrm{Co}, \mathrm{Cd}, \mathrm{Ni}, \mathrm{Pb}, \mathrm{Mn}, \mathrm{Cr}, \mathrm{Zn}, \mathrm{Fe}, \mathrm{As}$, and $\mathrm{Hg}$ ) were determined with atomic absorption spectroscopy (AAS) (GBC, Avanta Sigma, Australia). The detection of As was performed on inductively coupled plasma-optical emission spectrometer (ICP-OES, VARIAN720-ES).

To analyze the presence of different organic constituents in the pharmaceutical effluent, $50 \mathrm{~mL}$ of effluent was treated thrice with an equal volume of hexane (Koning et al. 2009). Extraction and derivatization of effluent sample were done using hexane and trimethyl silyl (BSTFA ( $N, O$ bis(trimethylsilyl)trifluoroacetamide) TMCS). Silylated sample $(1 \mu \mathrm{L})$ was injected in GC-MS (Ultra TSQ Quantum XLS Mass spectrometer, Thermo Scientific, USA). The injection step was operated in splitless injection mode with a column temperature of $250{ }^{\circ} \mathrm{C}$ and flow of carrier helium gas with the flow rate of $1.1 \mathrm{~mL} \mathrm{~min}{ }^{-1}$. The compounds were identified based on retention time (RT in minutes) and mass spectra obtained from full scan mode $(\mathrm{m} / \mathrm{z}, 45-800)$. 
Furthermore, FT-IR was done to identify the various organic functional groups. The effluent sample $(50 \mathrm{~mL}$ each) was evaporated and subsequently dried $\left(100^{\circ} \mathrm{C}\right)$. Finally, a solid mass was obtained for each sample by mixing them with potassium bromide ( $\mathrm{KBr}$ ) (AR, Merck) and pellet was prepared. The analyses were carried out on FT-IR spectrum scan of 500-4000 $\mathrm{cm}^{-1}$ (PerkinElmer Spectrum RXI).

For the cytotoxicity bioassay, onion bulbs were purchased from a local market of Lucknow, India. Six different concentrations $(\% \mathrm{v} / \mathrm{v})$ of pharmaceutical effluent (each $50 \mathrm{~mL}$ ), viz. $6.25,12.5,25,50,75$, and $100 \% \mathrm{v} / \mathrm{v}$, were prepared. Five onion bulbs of equal size were treated and incubated at $23{ }^{\circ} \mathrm{C}$ with each concentration type in separate $50-\mathrm{mL}$ Falcon ${ }^{\mathrm{TM}}$ tubes for 5 days. Dechlorinated tap water was used as a negative control and $5 \mathrm{mM}$ ethane methyl sulfonate (EMS) treatment as the positive control. The solutions were changed every $24 \mathrm{~h}$ until the end of treatment.

The genotoxicity studies were carried out with the help of five onion bulbs per effluent concentration grown in tap water initially for $48 \mathrm{~h}$. After that when root growth of 1-2 cm observed, it transferred into three different concentrations of effluents, viz. 6.25, 12.5, and 25\% (v/v), plus tap water as control (Chauhan and Sundararaman 1990). At the end of the exposure, root tips were extracted and fixed in Carnoy's solution [alcohol (98\% purity) and acetic acid (glacial 100\%) in 3:1 ratio] for $12 \mathrm{~h}$ at $4{ }^{\circ} \mathrm{C}$. After treatment, the residual fixative was removed by washing with distilled water (2-3 times) and subsequently hydrolyzed with $1 \mathrm{~N}$ $\mathrm{HCl}$ at $60{ }^{\circ} \mathrm{C}$ for 5-7 min. Hydrolyzed root tips were again washed with distilled water (2-3 times) and cut into pieces of approximately 1-2 mm. Afterward, staining of root tips was done with hematoxylin (Fiskesjo 1985; Chauhan and Sundararaman 1990). Finally, all the slides were studied under microscope to calculate the mitotic index percent (MI) and the score of chromosomal aberrations (CAs) percentage. MI was estimated by the use of numbers of dividing cells in mitosis phaseout of total number of observed cells per concentration. In our study, it was based on 1000 cells count (Fiskesjo 1985). CA was calculated as total aberrant cells/ total observed cells per concentrations.

The results of MI and CA were subjected to analysis of variance (ANOVA) test followed by Dunnett's post hoc multiple comparison tests. Statistical analysis was performed using STATISTICA 7.0.

\section{Results and discussion}

The effluent was dark red in color and slightly acidic ( $\mathrm{pH} 5.6 \pm 0.11$ ). We recorded high conductivity $\left(1563.34 \pm 176 \mu \mathrm{s} \mathrm{cm}^{-1}\right)$, total dissolved solids $\left(920.34 \pm 137 \mathrm{mg} \mathrm{L}^{-1}\right)$, BOD $\left(7253.34 \pm 1022 \mathrm{mg} \mathrm{L}^{-1}\right)$, and COD $\left(756.67 \pm 1124 \mathrm{mg} \mathrm{L}^{-1}\right)$ in the effluent sample
Table 1 Physicochemical characteristics of pharmaceutical effluent

\begin{tabular}{llll}
\hline Parameters & Range & Mean \pm SE & $\begin{array}{l}\text { Standard } \\
\text { permissible } \\
\text { value } \\
\text { CPCB }(2005)\end{array}$ \\
& & & $6.0-8.5$ \\
$\mathrm{pH}$ & $5.4-5.6$ & $5.6 \pm 0.11$ & 1000 \\
$\mathrm{EC}\left(\mu_{\mathrm{s} \mathrm{cm}}^{-1}\right)$ & $1230-1830$ & $1563.34 \pm 176$ & 2100 \\
$\mathrm{TDS}\left(\mathrm{mg} \mathrm{L}^{-1}\right)$ & $695-1170$ & $920.34 \pm 137$ & 100 \\
$\mathrm{BOD}\left(\mathrm{mg} \mathrm{L}^{-1}\right)$ & $5460-9000$ & $7253.34 \pm 1022$ & \\
$\mathrm{COD}\left(\mathrm{mg} \mathrm{L}^{-1}\right)$ & $11,980-15,840$ & $756.67 \pm 1124$ & 250 \\
$\mathrm{Heavy} \mathrm{metal} \mathrm{(mg} \mathrm{L}$ & & \\
$\mathrm{Cu}$ & $1.98-2.56$ & $2.21 \pm 0.19$ & 3 \\
$\mathrm{Co}$ & $0.26-0.53$ & $0.39 \pm 0.08$ & $\mathrm{NS}$ \\
$\mathrm{Cd}$ & $0.10-0.50$ & $0.27 \pm 0.12$ & 2 \\
$\mathrm{Ni}$ & $0.04-0.07$ & $0.05 \pm 0.01$ & 3 \\
$\mathrm{~Pb}$ & $0.58-1.2$ & $0.85 \pm 0.90$ & 0.1 \\
$\mathrm{Mn}$ & $0.58-1.05$ & $0.84 \pm 0.14$ & 2 \\
$\mathrm{Cr}$ & $1.47-1.51$ & $1.50 \pm 0.02$ & 2 \\
$\mathrm{Zn}$ & $2.61-3.5$ & $3.11 \pm 0.27$ & 5 \\
$\mathrm{Fe}$ & $1.72-2.13$ & $1.90 \pm 0.12$ & 3 \\
$\mathrm{As}$ & $0.05-0.09$ & $0.07 \pm 0.02$ & 0.2 \\
$\mathrm{Hg}$ & $0.003-0.006$ & $0.004 \pm 0.001$ & 0.01 \\
\hline
\end{tabular}

$N S$ not specified

(Table 1). The presence of heavy metals with their respective concentration in the effluent is obtained after the analysis with AAS instrument confirmed the presence of $\mathrm{Cu}, \mathrm{Co}, \mathrm{Cd}$, $\mathrm{Ni}, \mathrm{Pb}, \mathrm{Mn}, \mathrm{Cr}, \mathrm{Zn}, \mathrm{Fe}, \mathrm{As}$, and $\mathrm{Hg}$. The result confirmed that the parameters such as $\mathrm{pH}$, electrical conductivity (EC), BOD, and COD were above the standard prescribed limits of CPCB for effluent discharged into surface water. Comparative reviews with regard to physicochemical characterization were also carried out by various authors (Ramola and Singh 2013; Rohit and Ponmurugan 2013; Rao et al. 2004; Mayabhate et al. 1988; Vanerkar et al. 2013; Sirtori et al. 2009). The high BOD and COD indicated that the different chemical ingredients were used in the preparation of drugs (Hardman and Limbird 1996; Reynolds 1989).

GC-MS analyses of hexane-extracted effluent samples are presented in Fig. 1. GC-MS analyses of effluent sample on the basis of retention time (in minute) revealed the presence of various types of organic compound including trimethyl(phenylmethoxy) (RT=10.53), 1,6,8-trimethoxy2-isopropyl-3-methoxy-anthracene-9-one $(\mathrm{RT}=13.52)$, silane,(iodomethoxy)trimethyl $(\mathrm{RT}=15.41)$, hydroquinone $(\mathrm{RT}=16.19)$, monotrimethylsilyl derivative of nicotinamide $(\mathrm{RT}=17.67), 2,5$-dihydroxy benzyl alcohol 3 TMS (22.27), pantoyl propylamide, bis(trimethylsilyl) ether $(\mathrm{RT}=26.49)$, hexadecanoic acid, trimethylsilyl ester $(\mathrm{RT}=27.81)$, oleic acid, trimethylsilyl ester $(\mathrm{RT}=30.31)$, promethazine $(\mathrm{RT}=31.66)$, kurchessin $(\mathrm{RT}=32.26)$, tocopherol acetate $(\mathrm{RT}=40.78)$, and galactopyranoside, 


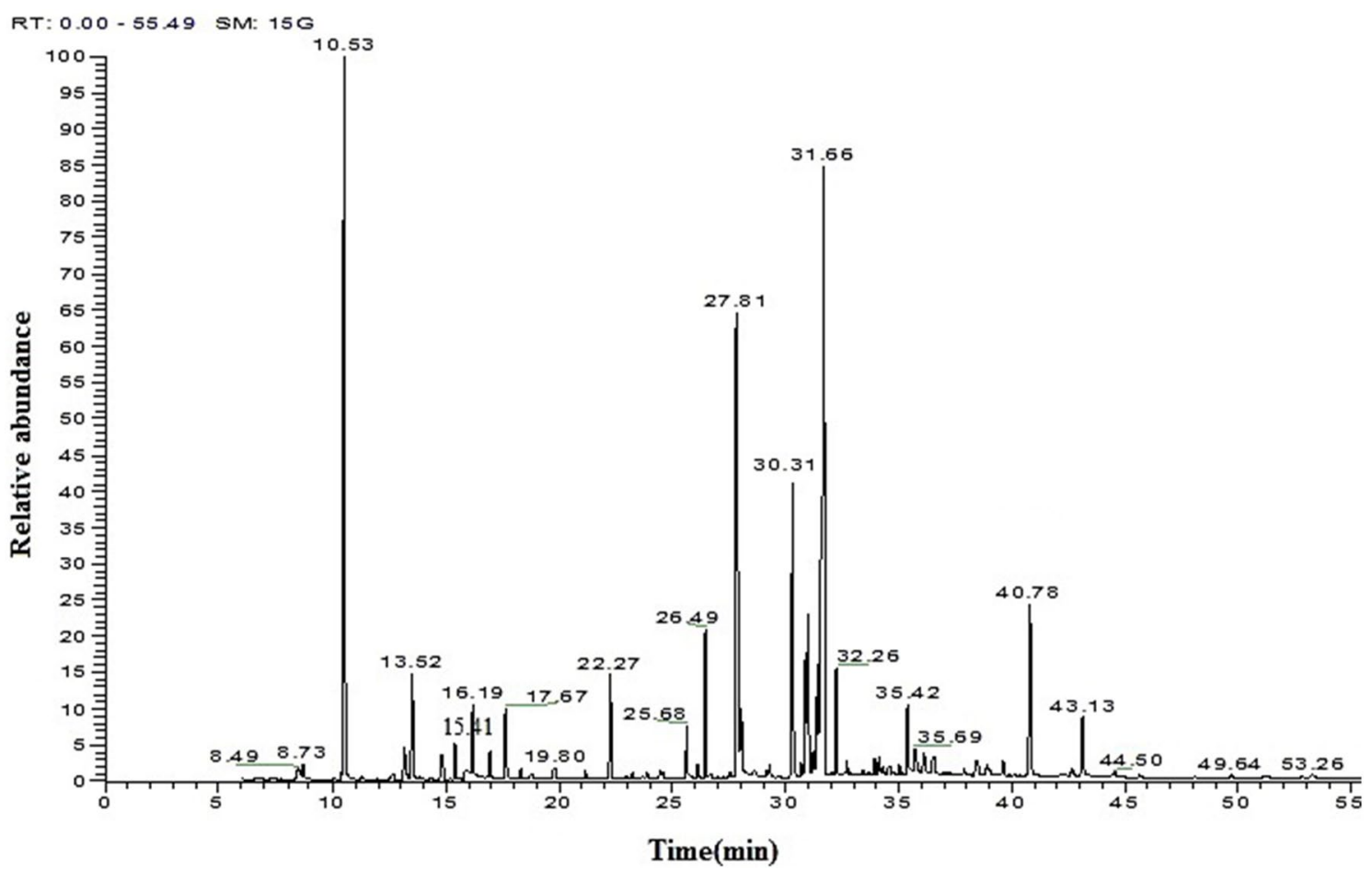

Fig. 1 Gas chromatogram of compounds extracted from pharmaceutical effluent

Fig. 2 Fourier-transform infrared spectroscopy analyses of pharmaceutical effluent

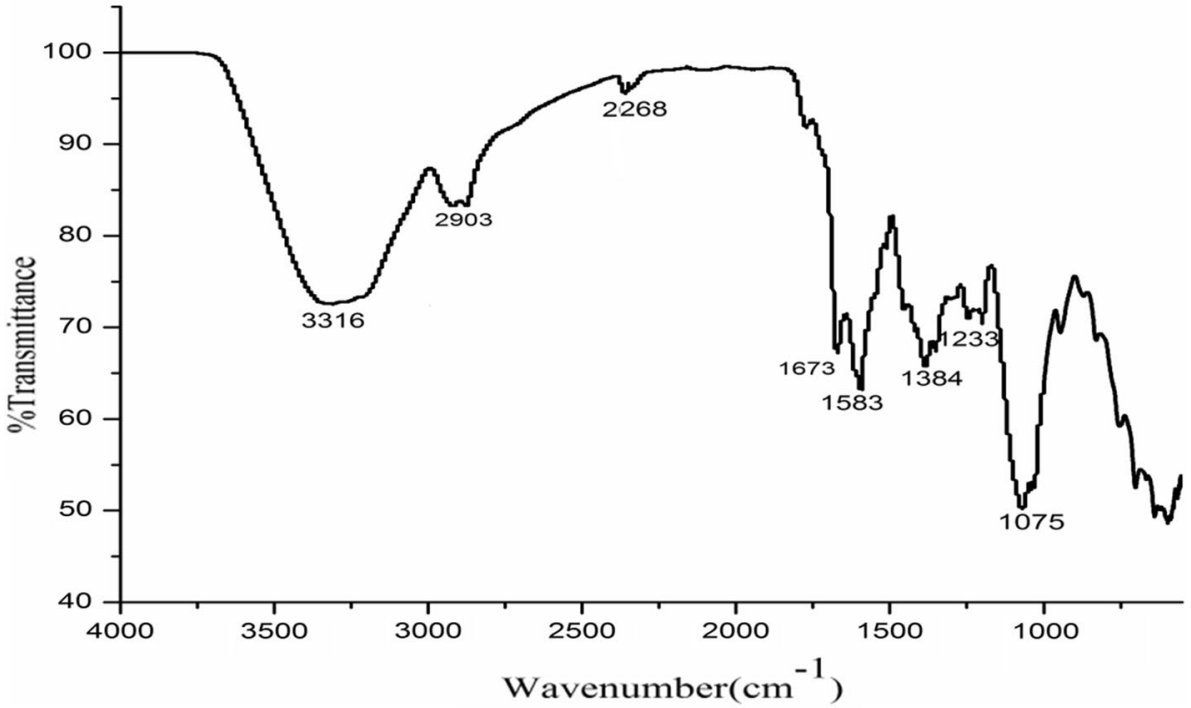

methyl 2,3-bis- $O(\mathrm{RT}=43.13)$ which were compared with standard of National Institute of Standards and Technology (NIST) library. The result indicates that mainly two drugs identified in the effluent are promethazine (used in treatment of allergies and motion sickness) and hydroquinone. Hydroquinone (used for skin bleaching) is an aromatic organic compound, a type of phenol, leading to serious toxic effects on fauna and flora. Pereira et al. (2014) reported that the hydroquinone drug has genotoxic property. The cytotoxicity of hydroquinone is caused by following the primarily oxidative damage methods to DNA (Enguita and Leitão 2013). The compound tocopherol acetate is also found that is used in the preparation of multivitamins tablets.

FT-IR analyses result (Fig. 2) shows that the peaks at $3316 \mathrm{~cm}^{-1}$ and $2903 \mathrm{~cm}^{-1}$ correspond to antisymmetric and symmetric $\mathrm{C}-\mathrm{H}$ stretching vibrations in methyl groups, $2268 \mathrm{~cm}^{-1}, 1673 \mathrm{~cm}^{-1}, 1583 \mathrm{~cm}^{-1}$, and $1384 \mathrm{~cm}^{-1}$ correspond to stretching and deformation vibrations of 


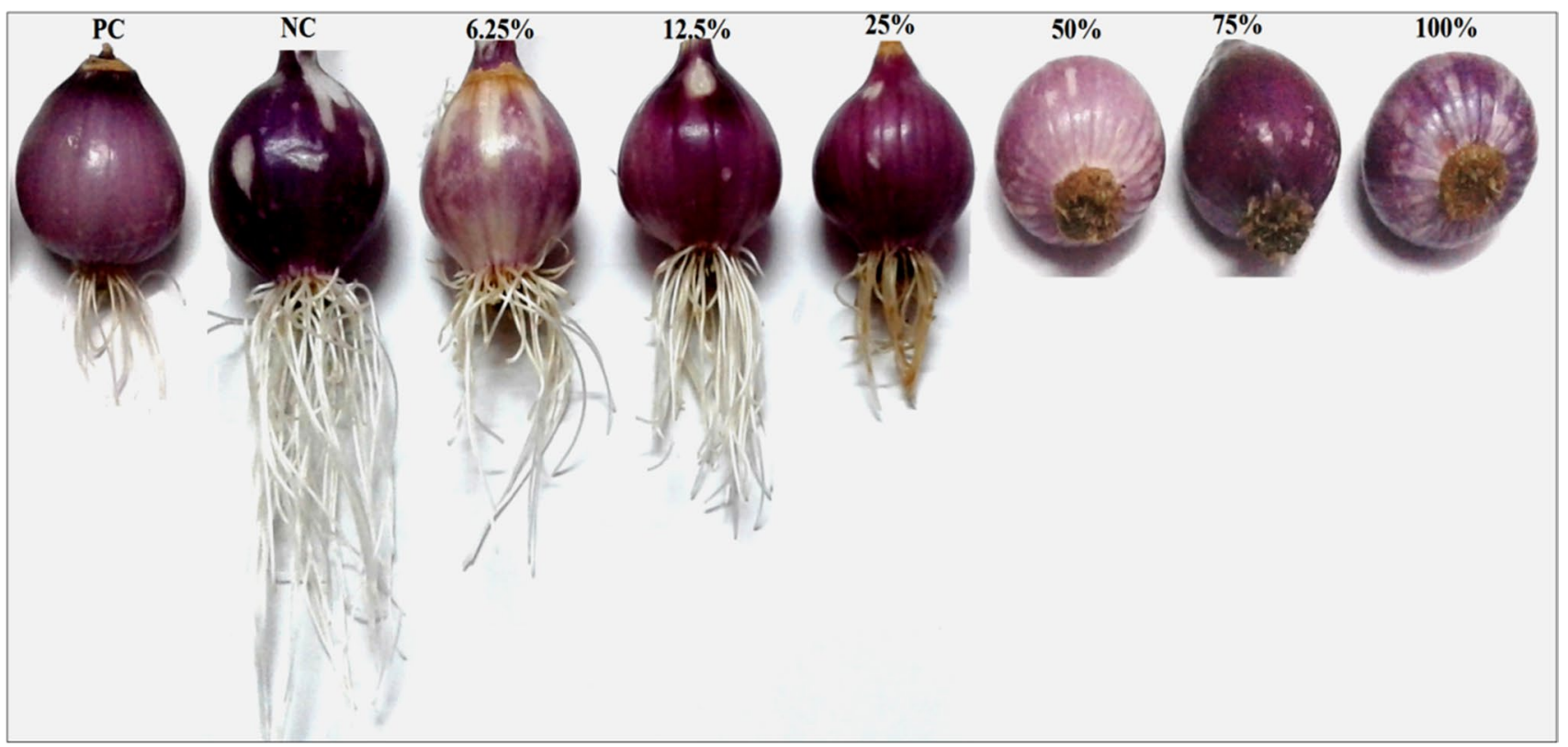

Fig. 3 PC positive control (EMS-5 mM), NC negative control (tap water), and 6.25\%, 12.5\%, and 25\% refer to treatments with different concentrations of pharmaceutical effluent

Table 2 Indices of chromosomal abnormalities observed in the root tip cells of onions grown in different concentrations of pharmaceutical effluent

\begin{tabular}{lllllr}
\hline Assay & NC & PC & \multicolumn{3}{l}{ Pharmaceutical effluent concentration (\%) } \\
\cline { 4 - 6 } & & & $6.25 \%$ & $12.5 \%$ & $25 \%$ \\
\hline Mitotic index (\%) & $64.1 \pm 0.68$ & $3.1 \pm 0.90^{*}$ & $25.0 \pm 0.70^{*}$ & $17.1 \pm 0.70^{*}$ & $9.6 \pm 0.51^{*}$ \\
Chromosomal aberrations & & & & \\
Stickiness & $0.0 \pm 0.0$ & $0.0 \pm 0.0$ & $11.6 \pm 0.9$ & $20.6 \pm 1.51$ & $31.4 \pm 0.19$ \\
Bridge & $0.0 \pm 0.0$ & $0.0 \pm 0.0$ & $7.2 \pm 0.59$ & $13.8 \pm 1.07$ & $25.4 \pm 0.82$ \\
Vagrant & $0.0 \pm 0.0$ & $0.0 \pm 0.0$ & $5.4 \pm 0.51$ & $12.2 \pm 1.07$ & $22.4 \pm 0.88$ \\
Tripolar & $0.0 \pm 0.0$ & $0.0 \pm 0.0$ & $4.4 \pm 0.51$ & $8.0 \pm 0.71$ & $17.4 \pm 0.88$ \\
Laggard & $0.0 \pm 0.0$ & $0.0 \pm 0.0$ & $4.0 \pm 0.45$ & $5.0 \pm 0.89$ & $9.4 \pm 0.82$ \\
c-mitosis & $0.0 \pm 0.0$ & $0.35 \pm 0.2$ & $0.0 \pm 0.0$ & $3.2 \pm 0.67$ & $4.6 \pm 0.51$ \\
Chromosomal break & $0.0 \pm 0.0$ & $0.6 \pm 0.31$ & $0.0 \pm 0.0$ & $1.6 \pm 0.51$ & $2.0 \pm 0.32$ \\
Micronuclei & $0.0 \pm 0.0$ & $0.9 \pm 0.41$ & $0.0 \pm 0.0$ & $1.4 \pm 0.51$ & $2.8 \pm 0.38$ \\
Aberrant cells $(\%)$ & $0.0 \pm 0.0$ & $0.25 \pm 0.2$ & $6.0 \pm 0.8 *$ & $12.0 \pm 0.49 *$ & $19.5 \pm 0.39 *$ \\
\hline
\end{tabular}

Values are mean $\pm \operatorname{SE}(n=5)$

*Values are statistically different $(p<0.01)$ for NC by ANOVA followed by Dunnett's test. NC negative control (tap water), PC positive control (EMS-5 mM)
$(\mathrm{C}=\mathrm{C})$ group, and peak 1233-1075 $\mathrm{cm}^{-1}$ shows the inplane deformed peak of benzene (Ermakova et al. 2015).

Onions grown in different concentrations of effluent showed toxic effects of effluent on root growth. Significant differences were noticed when roots length was compared with negative control (tap water). Root growth was not observed in onions grown in the effluent concentrations $\geq 50 \%$ (Fig. 3).

Inhibition in root growth and length of Allium cepa were observed in the present study following the treatment with pharmaceutical industrial wastewater which was in concurrence with previous studies conducted by other researchers (Akintonwa et al. 2009; Bakare et al. 2009).

The MI of onion root in the negative control (tap water) was $64 \%$, whereas MI obtained for the onion root in the positive control (5 mM EMS) was 3.1\% (Table 2). The lowest MI was recorded $(\mathrm{MI}=9.6 \%)$ in $25 \%$ concentration of effluent, showing a significant reduction compared to control $(p<0.01)$. The interference in MI may result from the cytotoxic effect which is in acquired by inheritance in the toxic effluent. The toxicants in effluent may interfere in the normal mitotic cell cycle by prohibiting cells from entering 


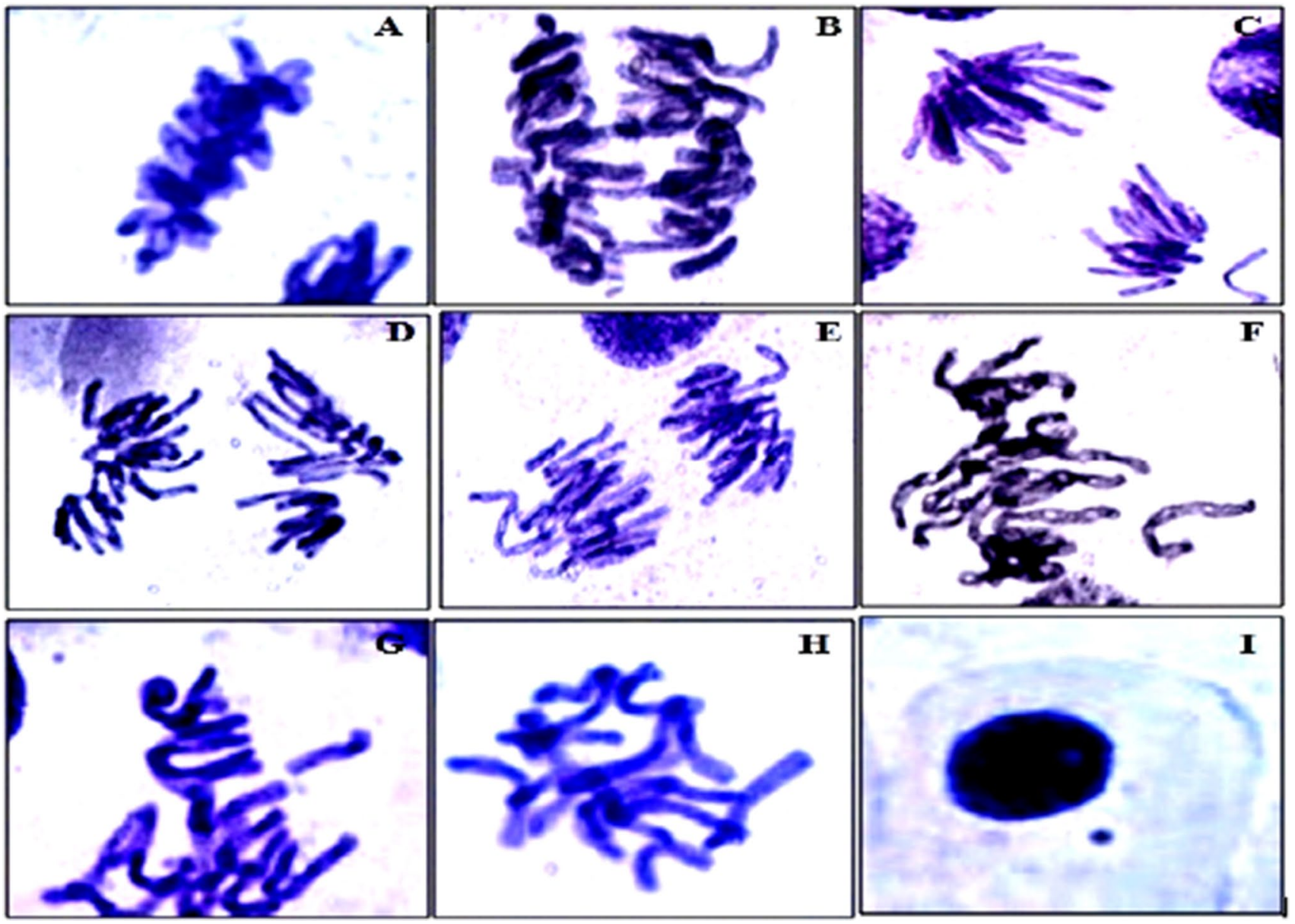

Fig. 4 Various stages of mitosis show chromosomal aberrationsstickiness (a), anaphase bridge (b), laggard (c), tripolar (d), vagrant (e), chromosomal loss (f), chromosomal break (g), c-mitosis (h), and

the prophase and thus blocking the mitosis during interphase (Shrivastava 2015; Glinska et al. 2007; Rencuzogullari et al. 2001). The reduction in MI can be assigned to the impact of toxic chemicals on DNA/protein synthesis of the biological system (Chauhan et al. 1998).

No chromosomal aberrations were observed in the root tip cells treated with the tap water (negative control) (Fig. 4 and Table 2). Onion bulbs grown in the positive control (5 mM EMS) showed c-mitosis, chromosomal break, and micronuclei in the root tip cells. The observed CA was stickiness, anaphase bridge, laggard chromosome, tripolar chromosome, vagrant chromosome, chromosomal loss, chromosomal break, c-metaphase, and micronucleated cell. Different chromosomal aberrations have been also reported by other researchers in their study (James et al. 2015; Akintonwa et al. 2009; Bakare et al. 2009). The highest CA was recorded $(19.5 \%)$ in $25 \%$ concentration of effluent. The indication of CA in A. cepa root tip cells may be incorporated with the collective effect of different pollutants such as heavy metals, phenols, drugs, and other organic pollutants micronucleated cell (i) in root tip cells of A. cepa treated with different concentrations of pharmaceutical effluent

(investigated by GC-MS). All these studies suggest that heavy metals, phenols, drugs, and other organic pollutants are responsible for cytotoxic and genotoxic effects of pharmaceutical effluent.

\section{Conclusion}

The present study finds out that the different heavy metals, phenols, drugs, and other organic compounds are the constituents of pharmaceutical effluent which is discharged into the wastewater. These constituents of pharmaceutical effluent are toxic in nature and can harm the environment. The various types of the raw materials which are used should be either modified or should be replaced with other nontoxic substances, and the manufacturing design and source of toxic substances should be reduced by employing various types of technological methods. The new concepts of zero liquid waste discharged should be involved in the waste disposal methods. It is critical to develop an integrated 
multidisciplinary treatment system which could efficiently degrade the pharmaceutical ingredients in the effluent before their discharge in the surrounding environment. The rules and regulations and norms of the pharmaceuticals industries should be strict. The monitoring of the pharmaceuticals industries should be carried out by the regulatory authority to check the illegal discharge of unused waste materials and wastewater in the environment, which pose health hazards for biotas when mixed with the water bodies.

Acknowledgements Authors are very thankful to Central Drug Research Institute-SAIF, Lucknow (India), for providing FT-IR analytical facility. Authors also acknowledge Director, Forest Research Institute, Dehradun, and Indian Institute of Toxicology Research, Lucknow (India), for providing laboratory facility for sample analyses. Authors are also thankful to University Grant Commission (UGC), New Delhi (India), for providing fellowship in the form of UGC JRF and extended SRF (UGC JRF/SRF Ref. No-3634 NET-December 2012).

Open Access This article is distributed under the terms of the Creative Commons Attribution 4.0 International License (http://creativeco mmons.org/licenses/by/4.0/), which permits unrestricted use, distribution, and reproduction in any medium, provided you give appropriate credit to the original author(s) and the source, provide a link to the Creative Commons license, and indicate if changes were made.

\section{References}

Adeoye GO, Alimba CG, Oyeleke OB (2015) The genotoxicity and systemic toxicity of a Pharmaceutical effluent in Wistar rats may involve oxidative stress induction. Toxicol Rep 2:1265-1272

Akintonwa A, Awodele O, Olofinnade AT, Anyakora C, Coker HAB, Afolayan GO (2009) Assessment of the mutagenicity of some pharmaceutical effluents. Am J Pharmacol Toxicol 4(4):144-150

Anetor JI, Adeniyi FA, Taylor GO (1999) Biochemical indicators of metabolic poisoning associated with lead based occupations in nutritionally disadvantaged communities. Afr J Med Med Sci 28(1-2):9-12

Anyakora C, Nwaeze K, Awodele O, Nwadike C, Arbabi M, Coker $\mathrm{H}$ (2011) Concentrations of heavy metals in some pharmaceutical effluents in Lagos, Nigeria. J Environ Chem Ecotoxicol $3(2): 25-31$

APHA (2005) Standard methods for the examination of water and wastewater. APHA, Washington

Babaahmadi F, Dobaradaran S, Pazira A, Eghbali SS, Khorsand M, Keshtkar M (2017) Data on metal levels in the inlet and outlet wastewater treatment plant of hospitals in Bushehr province. Iran. Data in Brief 10:1-5

Bakare AA, Alabi AO, Adetunji OA, Jenmi HB (2009) Genotoxicity assessment of a pharmaceutical effluent using four bioassays. Genet Mol Biol 32(2):373-381

Becker J (2010) Minding the gap: research priorities to address pharmaceuticals in the environment. UIC School of Public Health

Chauhan LKS, Sundararaman V (1990) Effect of substituted ureas on plant cells I. Cytological effects of isoproturon on the root meristem cells of Allium cepa. Cytologia 55(1):91-98

Chauhan LKS, Saxena PN, Sundararaman V, Gupta SK (1998) Diuron induced cytological and ultrastructural alterations in the root meristem cells of Alliums cepa. Pestic Biochem Physiol 62:152-163
Chelliapan S, Yuzir A, Md Din MF, Sallis PJ (2011) Anaerobic pretreatment of pharmaceutical wastewater using packed bed reactor. Int J Chem Eng Appl 2(1):32-37

Cleuvers M (2003) Aquatic ecotoxicity of pharmaceuticals including the assessment of combination effects. Toxicol Lett 142(3):185-194

CPCB (2005) Environmental standards for ambient air, automobile, fuel, industries and noise. Central Pollution Control Board, New Delhi, pp 88-89

Daughton CG, Ternes TA (1999) Pharmaceuticals and personal care products in the environment: agents of subtle change? Environ Health Perspect 107(6):907-993

Enguita FJ, Leitão AL (2013) Hydroquinone: environmental pollution, toxicity, and microbial answers. Bio Med Res Int. https:// doi.org/10.1155/2013/542168

Ermakova EN, Sysoeva SV, Nikulinaa LD, Tsyrendorzhievab IP, Rakhlinb VI, Kosinovaa ML (2015) Trimethyl (phenyl) silanea precursor for gas phase processes of $\mathrm{SiCx}$ : $\mathrm{H}$ film deposition: synthesis and characterization. Mod Electron Mater 1:114-119

Fiskesjo G (1985) The Allium tests as a standard in environmental monitoring. Hereditas 102(1):99-112

Glinska S, Bartczak M, Oleksiak S, Wolska A, Gabara B, Posmyk M, Janas K (2007) Effects of anthocyanin-rich extract from red cabbage leaves on meristematic cells of Allium cepa L. roots treated with heavy metals. Ecotoxicol Environ Saf 68(3):343-350

Hardman JA, Limbird GL (1996) Goodman and Gilman's the pharmacologic basis of therapeutics. McGraw Hill Co., New York

Hernandoa MD, Mezcua M, Fernandez-Alba AR, Barcelo D (2006) Environmental risk assessment of pharmaceutical residues in wastewater effluents, surface waters and sediments. Talanta 69(2):334-342

Idris MA, Kolo BG, Garba ST, Ismail MA (2013) Physico-chemical analysis of pharmaceutical effluent and surface water of River Gorax in Minna, Niger State, Nigeria. BEPLS 2(3):45-49

James OO, Oluwaleye SE, Olufunmilayo AE, Adebiyi OA (2015) Cytotoxic effects and genotoxic screening of pharmaceutical effluents using onion bulbs (Allium cepa L.). J Adv Biol Biotechnol 2(1):51-58

Jones OA, Voulvoulis N, Lester JN (2001) Human pharmaceuticals in the aquatic environment: a review. Environ Technol 22(12):1383-1394

Koning S, Janssen H-G, Brinkman UAT (2009) Modern methods of sample preparation for GC analysis. Chromatographia 69(S1):33-78

Larsson DGJ, de-Pedro C, Paxeus N (2007) Effluent from drug manufactures contains extremely high levels of pharmaceuticals. J Hazard Mater 148(3):751-755

Leme DM, Marin-Morales MA (2009) Allium cepa test in environmental monitoring: a review on its application. Mutat Res 682(1):71-81

Levan A (1938) The effect of colchicine on root mitosis in Allium. Hereditas 24:471-486

Mayabhate SP, Gupta SK, Joshi SG (1988) Biological treatment of pharmaceutical wastewater. Water Air Soil Pollut 38(1-2):189-197

Nadal M, Schuhmacher M, Domingo JL (2004) Metal pollution of soils and vegetation in an area with petrochemical industries. Sci Total Environ 321(1-3):59-69

Osaigbovo AE, Orhue ER (2006) Influence of pharmaceutical effluents on some soil chemical properties and early growth of maize (Zea mays L.). Afr J Biotechnol 5(12):1612-1618

Pereira P, Enguita FJ, Ferreira J, Leitão AL (2014) DNA damage induced by hydroquinone can be prevented by fungal detoxification. Toxicol Rep 1:1096-1105 
Ramola B, Singh A (2013) Heavy metal concentrations in pharmaceutical effluents of Industrial Area of Dehradun (Uttarakhand). Int J Environ Sci Res India 2(2):140-145

Rao AG, Naidu GV, Prasad KK, Rao NC, Mohan SV, Jetty A, Sharma PN (2004) Anaerobic treatment of wastewater with high suspended solids from a bulk drug industry using fixed film reactor (AFFR). Bioresour Technol 93(3):241-247

Rencuzogullari E, Kayraldiz A, Iia HB, Cakmak T, Topaktas M (2001) The cytogenetic effects of sodium metabisulphite, a food preservative in root tip cells of Allium cepa L. Turk J Biol 25:361-370

Reynolds J (1989) Martindale's: the extra pharmacopoeias, 29th edn. Pharmaceutical Press, London

Rohit CK, Ponmurugan P (2013) Physico-chemical analysis of textile automobile and pharmaceutical industrial effluents. Int J Latest Res Sci Technol 2(2):115-117

Shrivastava DK (2015) Cytotoxic effects of paper mill effluent on Allium cepa L. Int J Multidiscip Res Dev 2:657-661
Sirtori C, Zapata A, Oller I, Gernjak W, Aguera A, Malato S (2009) Decontamination of industrial pharmaceutical wastewater by combining solar photo-fenton and biological treatment. Water Res 43(3):661-668

Vanerkar AP, Satyanarayan S, Dharmadhikari DM (2013) Full scale treatment of herbal pharmaceutical industry wastewater. Int $\mathrm{J}$ Chem Phys Sci 2:52-62

Vuppala NVS, Suneetha C, Saritha V (2012) Study on treatment process of effluent in Bulk drug industry. Int Res Pharm Biomed Sci 3(3):1095-1102

Publisher's Note Springer Nature remains neutral with regard to jurisdictional claims in published maps and institutional affiliations. 